\title{
PERIOD OF INTENSE VEGETATION IN POLAND IN THE YEARS 1966-2015
}

\author{
ARKADIUSZ M. TOMCZYK, KATARZYNA SZYGA-PLUTA \\ Department of Climatology, Institute of Physical Geography and Environmental Planning \\ Adam Mickiewicz University, Poznan \\ atomczyk@amu.edu.pl
}

\begin{abstract}
The purpose of this paper was to determine long-range and spatial variability of the start and end dates of a period of intense vegetation in Poland in 1966-2015. The article is based on average monthly air temperature values acquired for 20 Polish stations for 1966-2015, made available by the Institute of Meteorology and Water Management - the National Research Institute. Based on the obtained data, the dates of the beginning and end of the intense vegetation period were determined. In this study, the intense vegetation period was defined as one with an average daily air temperature $\geq 10^{\circ} \mathrm{C}$. The mathematical formulas proposed by Gumiński (1948) were used to determine the dates of the beginning and end of the period.
\end{abstract}

A period of intense vegetation in Poland in the years 1966-2015 has extended. The dates of the beginning of the period of intense vegetation changed in the latitudinal system from the south to the north while the intensity of changes in the date of the beginning in the studied area was characterized by longitudinal distribution - the most prominent in the west of Poland. The end of the intense vegetation period occurs earliest in the north-east of Poland, and latest in the west and the south. The end date changes were less significant than the start date changes. The length of the intense vegetation period ranges from the north-east to the south-west of Poland, and the most dramatic changes occurred in the west and the south-east of Poland.

Keywords: period of intense vegetation, climate changes, Poland.

\section{INTRODUCTION}

The climate warming as we know it today is unquestionable, and the years of 1983-2012 are considered the warmest 30-year period in the last 1,400 years (IPCC 2013). Numerous studies from both Poland and Europe have shown that progressive warming has translated into extension of the vegetation period (Menzel and Fabian 1999; Chmielewski and Rötzer 2001; Chmielewski et al. 2004; Tomczyk and Szyga-Pluta 2016). The length of the vegetation season is essential for the selection and conditions for the development of crop plants, and thus affects the yield of plant production (Mager and Kopeć 2010). Stages of crop growth change while optimum results of field works depend largely on the time when the growing season starts (Węgrzyn 2007).

Tomczyk and Szyga-Pluta (2018) showed an increase in air temperature during the growing season in Poland, which was most intense in the southern regions of the country. The increase in air temperature did not improve the conditions 
of plant growth because in period in question was accompanied by a decrease in the total rainfall in almost all regions of the country. Climate warming also adversely affects agriculture by reducing yield of some crops as a result of hot stress and the deteriorating water balance (Nieróbca 2009). The increase in air temperature can promote development of heat-loving weeds, pests and an emergence of new plant diseases.

Detailed forecasts of changes in the air temperature in the next decades in Poland indicate its further increase (Piniewski et al. 2017). In the light of these facts, the forecasted changes in the length of the growing season in Poland become increasingly realistic (Nieróbca et al. 2013). Some scholars indicate that by 2030 , the growing season in central Poland may be longer in comparison with the reference period of $1971-2000$ by 10-14 days and, by 2050 it will be 18-27 days longer, while in the south-western Poland by 11-17 days and 22-30 days, respectively. In accordance with the agro-climatic conditions scenarios in the 2050 perspective, constructed by Szwejkowski and others (2008), the expected shortest periods of intense growth can last as many days as now while the expected maximum duration may exceed today's maximum by almost two months. The aim of this study was to determine the long-range and spatial variability of the start and end dates of a period of intense vegetation and its length in Poland in 1966-2015. This research is a continuation of research conducted in northwestern Poland (Tomczyk and Szyga-Pluta 2017).

\section{DATA AND RESEARCH METHODS}

The basis for the study was the average monthly air temperature in 19662015 from 20 stations located in Poland (Figure 1). The data have been provided by the Institute of Meteorology and Water Management - the National Research Institute.

Based on the obtained data, the start and end dates of an intense vegetation period were determined. In this study, the time was defined as a period of an average daily air temperature $\geq 10^{\circ} \mathrm{C}$. The adopted definition was commonly used in earlier studies by other authors (Szwejkowski et al. 2008; Kopeć 2009; Żarski et al. 2012; Żmudzka 2012). The period with the average daily temperature above $10^{\circ} \mathrm{C}$ is also referred to as the forest growing season (Durło 2010). The temperature of $10^{\circ} \mathrm{C}$ is decisive for the vegetative and, above all, for the generative development of trees (Rubner 1960).

The mathematical formulas proposed by R. Gumiński (1948) were used to determine the start and end dates of the above mentioned period. In this method, the following assumptions are made: the monthly average temperature falls on the $15^{\text {th }}$ day of a month, each month has 30 days, and the monthly temperature changes are evenly distributed. The following formulas were used: 


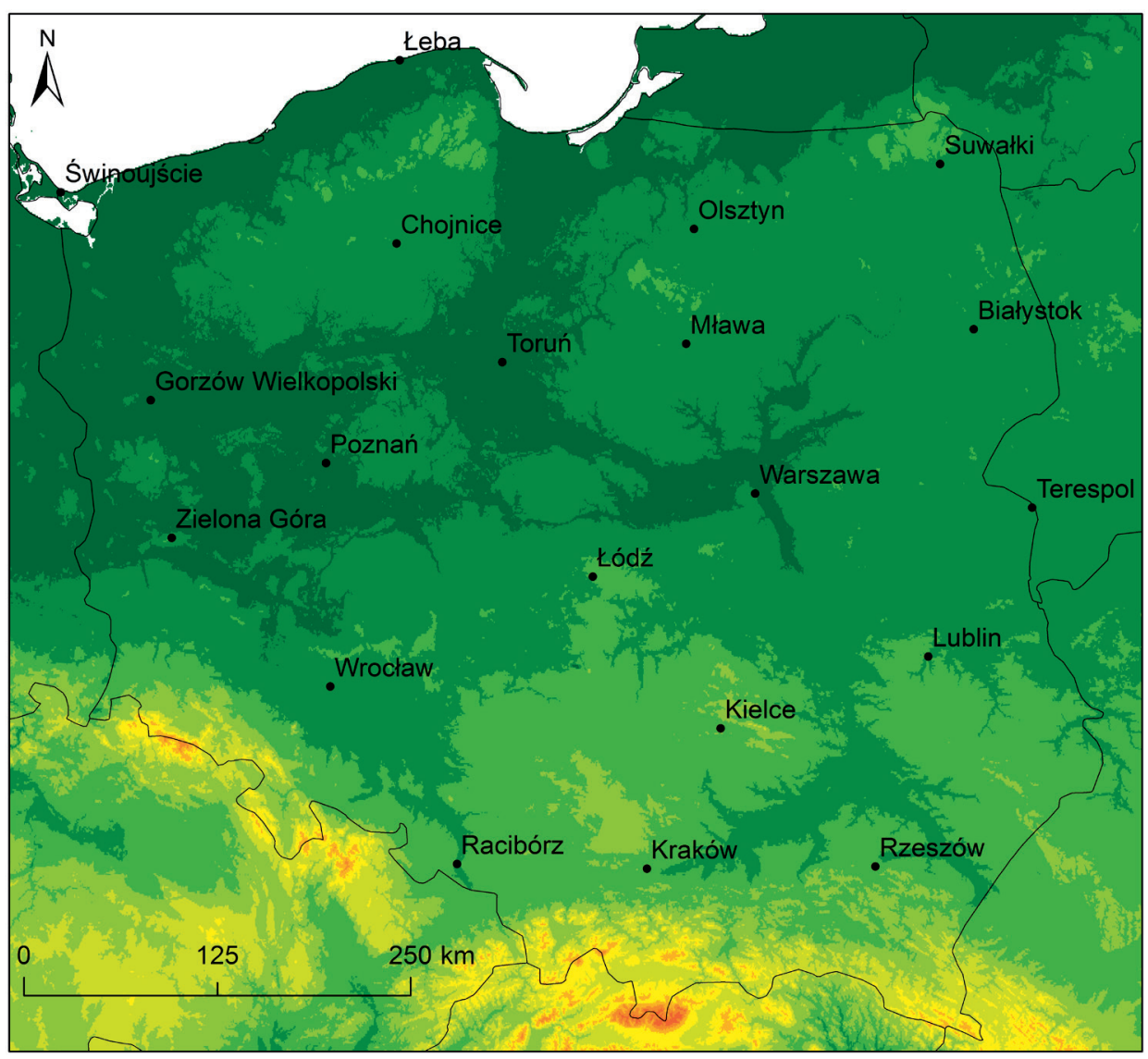

Fig. 1. Location of the weather stations

$$
\begin{aligned}
& x=30[(t p-t 1) /(t 2-t 1)] \\
& x=30[(t 1-t p) /(t 1-t 2)]
\end{aligned}
$$

where:

tp - threshold temperature;

$\mathrm{t} 1$ - average temperature in the month preceding the threshold temperature;

$\mathrm{t} 2$ - average temperature in the month following the threshold temperature;

$\mathrm{x}$ - number of days between the day with the threshold temperature and the $15^{\text {th }}$ day of the preceding month.

The aforementioned method is commonly adopted in the determination of thermal periods (Skowera and Kopeć 2008, Szyga-Pluta 2011ab, KępińskaKasprzak and Mager 2015, Tomczyk and Szyga-Pluta 2018).

Next, the length of the determined periods in the specific years was calculated together with the potential length in the examined multi-year period, i.e. the time between the earliest start and the latest ending of this period. The 
mean values, standard deviation and line trends were calculated for the abovementioned characteristics. In order to assess the nature of the changes, the linear regression model was used. On the other hand, evaluation of the statistical significance of the directional coefficient was made on the basis of Student's t-test at the level of $p<0.05$.

\section{RESULTS}

In the years 1966-2015, the period of intense vegetation started on average on 27 April. Its earliest beginning was recorded in central and southern Poland, while the latest in the north (Fig. 2A). In individual stations, the average start date of the intense vegetation period varied from 22 April in Racibórz and Wrocław to 11 May in Łeba. In most stations, the earliest beginning of the period was recorded in 2000 (typically the first decade of April), while the latest in 1980 (typically the second decade of May). The extreme dates of the beginning of the intense vegetation period fluctuated between 4 April in Wrocław and Zielona Góra to 29 May in Łeba. The above mentioned dates show that the potential time of the beginning of an intense vegetation period in Poland amounted to 56 days. In the investigated years, an increasingly early beginning of an intense vegetation period was identified. The observed changes, apart from Białystok, were statistically significant. The intensity of the changes in the studied area was characterized by longitudinal distribution (Fig. 2B). The smallest changes were identified in the eastern regions (Białystok -1.3 days/10 years) while the largest in the west of the country (Wrocław -3.6 days/10 years).

The end of an intense vegetation period in Poland was recorded on average on 4 October. The period ended earliest in north-eastern Poland and latest in western and southern Poland and on the coast (Fig. 3A). In individual stations, the average end date of an intense vegetation period changed from 25 September
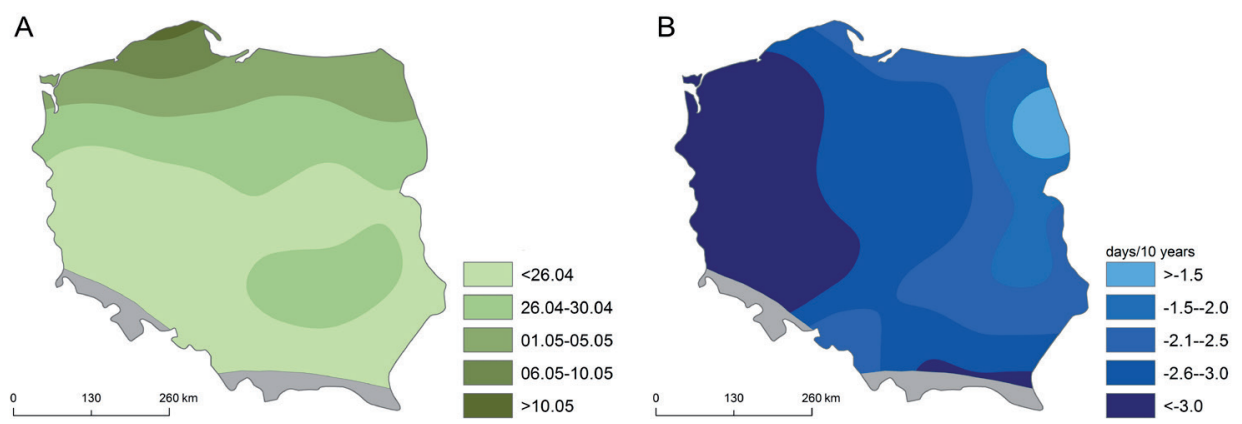

Figure 2. Average date (A) and changes in the beginning date of the period (B) of intense vegetation in Poland in 1966-2015. 
in Suwałki to 12 October in Świnoujście. In half of the stations, the period ended earliest in 1972 while in the other stations it was recorded in 1976, 1977, 1978, 1986 or 1996. In a vast majority of stations, the latest ending of the period occurred in 2000. Extreme dates of the ending of an intense vegetation period fluctuated from 9 September in Suwałki to 1 November in Racibórz. These dates show that the potential time of the ending of intense vegetation in Poland amounted to 54 days. In the considered multi-year period, the end of an intense vegetation period was found to be increasingly late, although these changes were not statistically significant (Figure 3B).

The average length of intense vegetation in Poland was 162 days; the period increased from the north-east to the south-west (Figure 4A). In individual stations, the average length of the period ranged from 146 days in Suwałki to 172 days in Racibórz and Wrocław. The variability of the length of the period in the country was similar, as indicated by the values of standard deviation which fluctuated at a similar level of 11-13 days. In the considered multi-year period, in a majority of stations the shortest period of intense vegetation occurred in 1980, while the longest in 2000. The study showed an increase in the duration of the
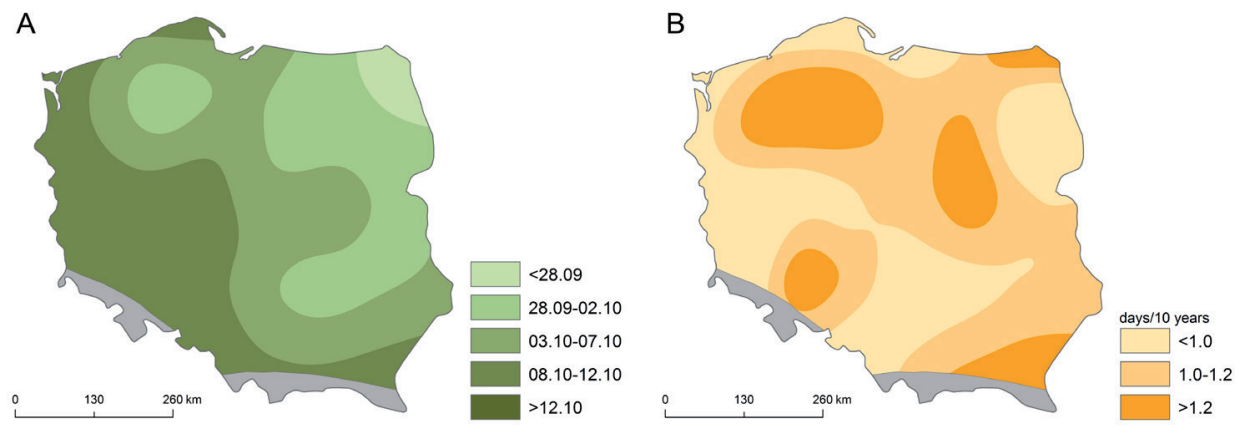

Fig. 3. Average date (A) and changes to the ending date of (B) intense vegetation in Poland in 1966-2015
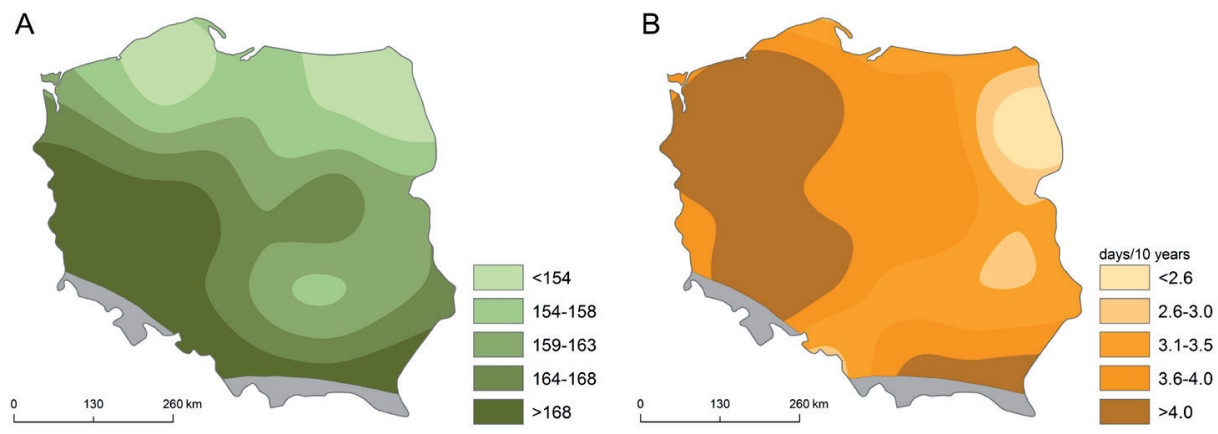

Fig. 4. The average length of intense vegetation (A) and its changes (B) in Poland in 1966-2015. 
growing season, statistically significant in all stations (except for Białystok). As was the case of the changes in the beginning of the period, longitudinal distribution was identified in the changes in the duration of the period (Figure 4B). The most intense increase in the length of intense vegetation was recorded in the western regions with the maximum recorded in Wrocław (4.9 days/10 years).

As indicated above, the shortest period of intense vegetation in most stations was recorded in 1980. The length of this period ranged from 124 days in Suwałki to 148 days in Gorzów Wielkopolski. In the entire examined area, this period was shorter than average in the analysed 50-year period, and deviations from the average value ranged from 18 days in Chojnice and Świnoujście to 28 days in Lublin. The shortening of the period in the analysed year was mainly attributed to its later beginning which fluctuated between 12 May in Gorzów Wielkopolski and 27 May in Łeba (Figure 5A). In individual stations, the delay in the beginning of the period ranged from 16 days in Łeba and Świnoujście to 25 days in Lublin. On the other hand, the end of the period ranged from 24 September in Suwałki to 10 October in Świnoujście (Figure 5B). As for the end of the period,
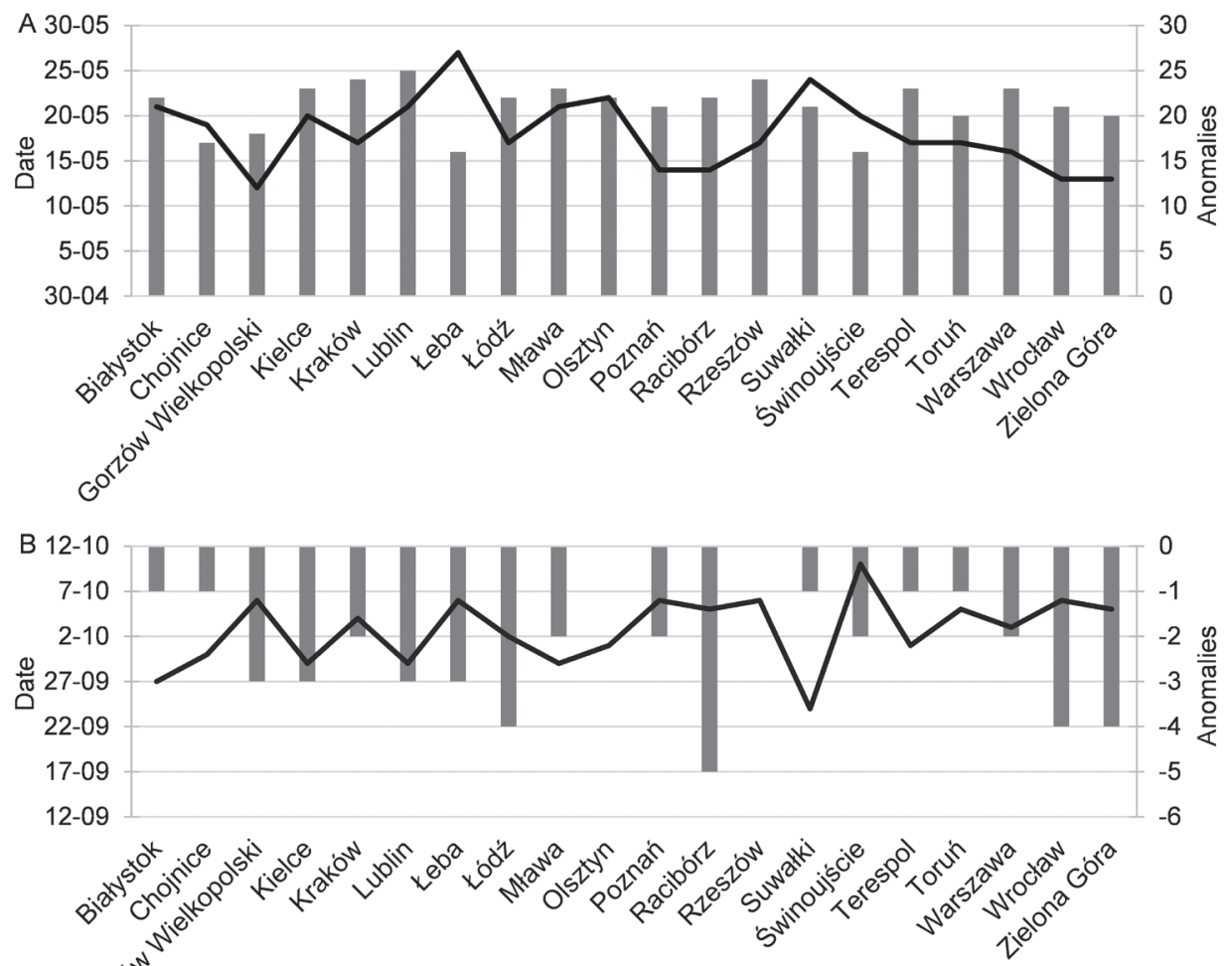

Fig. 5. Start (A) and end (B) dates of intense vegetation in 1980 (line) and deviations from the average long-range date (bars). 
deviations from the average value in the multi-year period were insignificant or non-existent.

However, the longest period of intense vegetation in a majority of the research area was recorded in 2000. The length of this period ranged from 158 days in Suwałki to 209 days in Racibórz. In all the stations, this period was longer than average in the analysed multi-year period by 12 days in Suwałki and 42 days in Chojnice. The extended growing season in 2000 was caused by a coinciding early start and later ending (apart from Suwałki). The beginning of the period ranged from 5 April in Wrocław and 16 April in Łeba (Figure 6A) while the ending from 15 September in Suwałki and 1 November in Racibórz (Figure 6B). In the individual stations, the advancement of the beginning of the period in relation to the average date from the multi-year period ranged from 15 days in
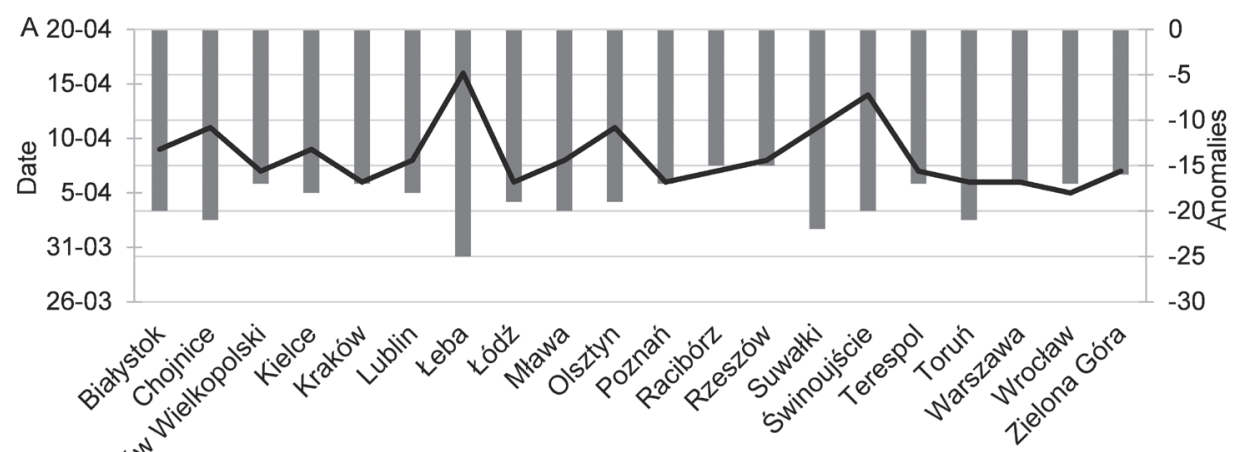

B $\begin{array}{r}6-11 \\ 1-11\end{array}$
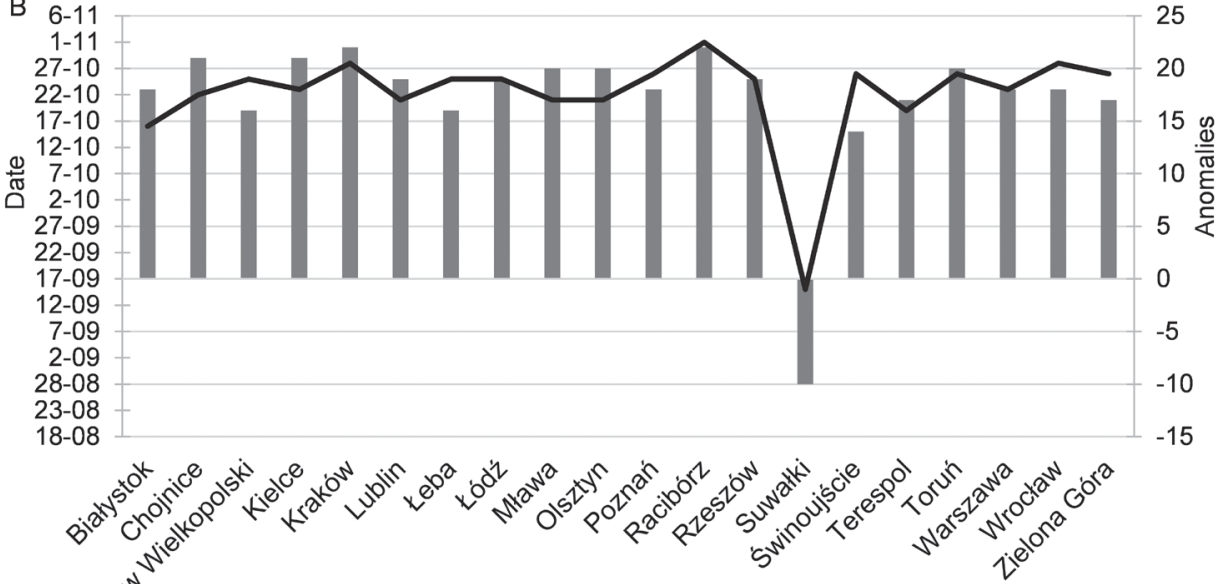
$\cos ^{2 i^{n}}$

Fig. 6. Start (A) and end (B) dates of intense vegetation in 2000 (line) and deviations from the average long-range date (bars). 
Racibórz and Rzeszów to 25 days Łeba, and the delay in the ending from 14 days in Świnoujście to 22 days in Krakow and Racibórz. Only in Suwałki, the end of the period occurred 10 days earlier.

\section{DISCUSSION AND SUMMARY}

In the years 1966-2015, the period of intense vegetation in Poland on average began on 27 April and ended on 4 October. The average length of the analysed period was 162 days. The spatial differentiation of the duration of the period with the temperature above $10^{\circ} \mathrm{C}$, as in the case of the other thermal periods, was very clear - the duration increased from the north-east to the south-west of the country. This differentiation characterized the spatial distribution of the duration and the start and end dates of the intense vegetation period both in the years with the shortest and the longest periods. The beginning of the intense vegetation period took place earliest in central and southern Poland, latest on the coast. The period's earliest ending took place in north-eastern Poland while the latest in western and southern Poland. In the analysed period, an intense plant growth period started increasingly early. The biggest changes took place in western Poland (Wrocław -3.6 days/10 years) and the smallest in the east (Białystok -1.3 days/10 years). By contrast, the end of the analysed period came later. The reason why the period of intense vegetation in Poland extended were primarily the increasingly early dates of the season's beginning. The increase in the length of intense growth is most pronounced in western Poland (Wrocław 4.9 days/10 years) and on the southeastern fringe. The extension of this period was already in line with the results obtained for various regions in Poland by other authors like OlechnowiczBobrowska and Wojkowski (2006), Skowera and Kopeć (2008) and Żmudzka (2012). According to Żmudzka (2012), in 1950-2006 in the lowland part of Poland, the period of intense vegetation was extended and the number of days with an average temperature of at least $10^{\circ} \mathrm{C}$ increased at the rate of $\sim 0.3$ days per year, which was also associated with a significant increase in thermal resources in the period in mind. In the Lublin region, the time variation of the end dates of the growing season is smaller compared to the start dates, as shown by Węgrzyn (2007ab). A period of intense vegetation got longer in this area (Węgrzyn et al. 2017). According to Skowera and Kopeć (2008), in south-eastern Poland the period of intense vegetation was extended, mainly due to an earlier start by 6-9 days in 1971-2000 compared with 1951-1980. According to Kopeć (2009), the average duration of intense vegetation for 1971-2000 amounted to 163 days in south-eastern Poland while in 19712000 , it extended by 3 days and amounted to 166 days. However, studies by Żarski et al. (2012) revealed no significant trends in the changes of indicators 
characterizing the agricultural thermal periods in the region of Bydgoszcz between 1981 and 2010. The extension of the period's time variability with temperature of above $10^{\circ} \mathrm{C}$ in 1996-2010 in relation with the previous 15 -year period (1981-1995) in Bydgoszcz may, as the authors conclude, be interpreted as an indication of the observed climate change.

According to Węgrzyn et al. (2017), the documented variability of the start and end dates coupled with the length of agricultural thermal periods in the Lublin region in the subsequent decades (1981-2010) as well as the tendencies to their extension reflect the rate of temperature increase.

In summary, it can be concluded that:

1. The period of intense vegetation in Poland in 1966-2015 was extended.

2. The start dates of intense vegetation change in the latitudinal system from the south to the north, while the intensity of changes in the start dates in the studied area was characterized by a meridional distribution - the most dramatic changes in the date occurred in the west of Poland.

3. The end of intense vegetation occurs earliest in the north-eastern part of Poland, and latest in the west and south. End date changes are less significant than the start dates.

4. The length of intense vegetation increases from the north-east to the south-west of Poland, and the biggest changes occurred in the west and the south-east of Poland.

\section{REFERENCES}

Chmielewski F.M., Rötzer T., 2001: Response of tree phenology to climate change across Europe, Agricultural Forest Meteorology, 108, 101-112.

Chmielewski F.M., Muller A., Bruns E., 2004: Climate changes and trends in phenology of fruit trees and field crops in Germany, 1961-2000, Agricultural Forest Meteorology, 121, 1-2, 69-78.

Durło G.B., 2010: Leśny okres wegetacyjny na obszarze LKP Lasy Beskidu Ślaskiego, Sylwan $154,8,577-584$.

Gumiński R., 1948: Próba wydzielenia dzielnic rolniczo-klimatycznych w Polsce, Przegląd Meteorologiczno- Hydrologiczny, Warszawa.

IPCC, 2013: Climate change: The physical science basis. Contribution of Working Group I to the Fifth Assessment Report of the Intergovernmental Panel in Climate Change, Cambridge University Press, Cambridge.

Kępińska-Kasprzak M., Mager P., 2015: Thermal growing season in Poland calculated by two different methods, Annals of Warsaw University of Life Sciences-SGGW Land Reclamation, 47, 3, 261-273.

Kopeć B., 2009: Uwarunkowania termiczne wegetacji winorośli na obszarze poludniowowschodniej Polski, Infrastruktura i Ekologia Terenów Wiejskich, 4, 251-262.

Mager P., Kopeć M., 2010: Okres wegetacyjny w Polsce $i w$ Europie $w$ dobie obserwowanego ocieplenia, [in:] E. Bednorz, L. Kolendowicz (ed.), Klimat Polski na tle klimatu Europy. Zmiany i ich konsekwencje, Bogucki Wydawnictwo Naukowe, Poznań, 49-63.

Menzel A., Fabian P., 1999: Growing season extended in Europe, Nature, 397, 659. 
Nieróbca A., 2009: Skutki zmian klimatycznych dla rolnictwa w Polsce - ocena zagrożeń, [in:] J. Kozyra, A. Nieróbca, K. Mizak (ed.), Zmiany klimatyczne a rolnictwo w Polsce - ocena zagrożeń i sposoby adaptacji. Puławy. IUNG-PIB.

Nieróbca A., Kozyra J., Mizak K., Wróblewska E., 2013: Zmiana długości okresu wegetacyjnego $w$ Polsce, Woda-Środowisko-Obszary Wiejskie, 13, 2 (42), 81-94.

Piniewski M., Mezghani A., Szcześniak M., Kundzewicz Z., 2017: Regional projections of temperature and precipitation changes: Robustness and uncertainty aspects, Meteorologische Zeitschrift, 26, 223-234.

Rubner K., 1960: Die pflanzengeographischen grundlagen des waldbaus, Neudamm-Neumann.

Skowera B., Kopeć B., 2008: Okresy termiczne w Polsce poludniowo-wschodniej (1971-2000), Acta Agrophysica, 12, 2, 517-526.

Szwejkowski Z., Dragańska E., Banaszkiewicz B., 2008: Scenariusze warunków agroklimatycznych okolic Olsztyna $w$ perspektywie spodziewanego globalnego ocieplenia w roku 2050, Acta Agrophysica, 12(2), 543-552.

Szyga-Pluta K., 2011a: Termiczne pory roku w Poznaniu w latach 2001-2008, Przegląd Geograficzny, 83, 1, 109-119.

Szyga-Pluta K., 2011b: Zmienność termicznych pór roku w Poznaniu, Badania Fizjograficzne, 62, 181-195.

Tomczyk A.M., Szyga-Pluta K., 2016: Okres wegetacyjny w Polsce w latach 1971-2010, Przegląd Geograficzny, 88, 1, 75-86.

Tomczyk AM., Szyga-Pluta K., 2017: The period of intense vegetation growth and maturing of plants in north-western Poland, Badania Fizjograficzne, 68, 189-203.

Tomczyk AM., Szyga-Pluta K., 2018: Variability of thermal and precipitation conditions in the growing season in Poland in the years 1966-2015, Theoretical and Applied Climatology, doi. org/10.1007/s00704-018-2450-4.

Węgrzyn A., 2007a: Ocena okresu wegetacyjnego na Lubelszczyźnie w latach 1951-1990. I. Klasyfikacja dat początku, Annales Universitatis Mariae Curie-Skłodowska Lublin - Polonia, 62(1), 23-30.

Węgrzyn A., 2007b: Ocena okresu wegetacyjnego na Lubelszczyźnie w latach 1951-1990. II. Klasyfikacja dat końca, Annales Universitatis Mariae Curie-Skłodowska Lublin - Polonia, 62(1), 31-37.

Węgrzyn A., Wojkowski J., Skowera B., 2017: Rolnicze okresy termiczne na Lubelszczyźnie w latach 1981-2010, Acta Agrophysica, 24(3), 535-551.

Żarski J., Renata Kuśmierek-Tomaszewska R., Stanisław Dudek S., 2012: Tendencje zmian termicznych okresów rolniczych w rejonie Bydgoszczy, Infrastruktura i Ekologia Terenów Wiejskich, 3, I, 7-17.

Żmudzka E., 2012: Wieloletnie zmiany zasobów termicznych w okresie wegetacyjnym i aktywnego wzrostu roślin w Polsce, Woda-Środowisko-Obszary Wiejskie, 12, 2 (38), 377-389. 